2013, Vol. 2, Issue 1

\title{
PUBLIC SERVICE COMPENSATION IN LAND TRANSPORT WHEN DOES IT NOT CONSTITUTE STATE AID?
}

\author{
Stefan A. Jarecki
}

Public services in land transport require significant funding from public sources. It is worth emphasizing that the overall amount of state aid in the form of public service compensation in land transport granted by the Polish authorities in 2010 to public service operators amounted to 2,54 billion zloty. ${ }^{1}$ The question therefore arises as to whether public service compensation in land transport constitutes state aid?

According to the Article 107(1) of the Treaty on the functioning of the European Union:

save as otherwise provided in the Treaties, any aid granted by a Member State or through State resources in any form whatsoever which distorts or threatens to distort competition by favouring certain undertakings or the production of certain goods shall, in so far as it affects trade between Member States, be incompatible with the internal market.

* Stefan Jarecki, PhD candidate - Faculty of Law and Administration, University of Cardinal Stefan Wyszyński; participant in Warsaw Seminary of Axiology of Administration; Senior Expert, Department of State Aid Monitoring, Office of Competition and Consumer Protection. The views expressed in this article are the author's own and should not be attributed to the Office of Competition and Consumer Protection.

1 Raport o pomocy publicznej w Polsce udzielonej przedsiębiorcom w 2010 roku [Report - state aid granted to undertakings in Poland in 2010], Urząd Ochrony Konkurencji i Konsumentów, Warszawa 2011, at pp. 47-48. 
Public service compensation in land transport is classified as state aid if the following conditions are cumulatively satisfied:

- compensation is granted by a Member State or through state resources,

- compensation confers an advantage on the undertaking,

- compensation is selective in the sense that it favours certain undertakings or the production of certain goods,

- compensation distorts or threatens to distort competition and affects trade between Member States.

Public service compensation in land transport usually constitutes state aid. First, since such compensation is paid by the public authorities from the public budget, it is granted through state resources. Sometimes public service compensation (especially in the new Member States) is co financed from the Cohesion Fund. It is worth mentioning that the resources of the Cohesion Fund which are transferred to the national budget and the budget of the regions prior to being paid to beneficiaries (public service operators) are considered to be at the disposal of the relevant Member State. ${ }^{2}$ Second, the compensation is usually given to a particular undertaking(s) or to some parts of the transport sector and therefore is considered to be selective. Public service compensation almost always threatens to distort competition in the internal market and affects trade between Member States, even if such public subsidy is granted to an undertaking which provides only local or regional transport services and does not provide any transport services outside its state of origin. As stated by the Court of Justice of the European Union in the Altmark judgement: ${ }^{3}$

Where a Member State grants a public subsidy to an undertaking, the supply of transport services by that undertaking may for that reason be maintained or increased with the result that undertakings established in other Member States have less chance of providing their transport

2 See Commission State Aid Decision No. 469/2008 of 28.1.2009 on State aid, Czech Republic, concerning Interoperability in rail transport (signaling system, telematics in freight transport, implementing measures with regard to rolling stocks), O.J. 6.3.2009, C-53, at para. 31; full text available at: http://ec.europa.eu/competition/ elojade/isef/index.cfm.

3 Altmark Trans GmbH, Regierungspräsidium Magdeburg v Nahverkehrsgesellschaft Altmark GmbH, Case No. C-280/00, Judgment of 24.7.2003, E.C.R. 2003, p. I-07747. 
services in the market in that Member State (...). Several Member States have since 1995 started to open certain transport markets to competition from undertakings established in other Member States, so that a number of undertakings are already offering their urban, suburban or regional transport services in Member States other than their State of origin. ${ }^{4}$

However, the question arises as to whether public service compensation in land transport provides an advantage to the recipient undertaking.

Public services compensation does not constitute state aid when the four criteria laid down by the Court of Justice in the Altmark judgment are met. According to the Court of Justice, if these criteria are met an undertaking does not receive any economic advantage. Since the Altmark criteria are cumulative, where at least one of them is not met, but the other state aid criteria are fulfilled, public service compensation is deemed to constitute state aid. In such a situation, public service compensation is subject to Articles 93, 106, 107 and 108 of the Treaty. In the Altmark judgment, the Court provided the following criteria:

- the recipient undertaking must have public service obligations and the obligations must be clearly defined;

- the parameters for calculating the compensation must be objective, transparent and established in advance;

- the compensation cannot exceed what is necessary to cover all or part of the costs incurred in the discharge of the public service obligations, taking into account the relevant receipts and a reasonable profit;

- where the undertaking which is to discharge public service obligations is not chosen pursuant to a public procurement procedure which would allow for the selection of the tenderer capable of providing those services at the least cost to the community, the level of compensation needed must be determined on the basis of an analysis of the costs of a typical, well-run and adequately equipped undertaking. ${ }^{5}$

The first Altmark criterion refers to the existence of the public service obligation and to the proper definition of this obligation. This

4 Case No. C-280/00, at para. 78-79.

5 Case No. C-280/00, at para. 89-93. 
criterion is fulfilled when the public service obligation imposed on the undertaking is clearly and specifically defined in the public service contract or a legislative or regulatory act. The public service obligation may also be laid down in several acts ${ }^{6}$. Definition of the public service obligation may contain such elements as the lines covered by public services, punctuality, quality and frequency standards. ${ }^{7}$ Moreover the service provided by the undertaking receiving compensation must be services of general economic interest (SGEI) within the meaning of the Treaty. The Court of Justice has established that SGEIs are services that exhibit special characteristics when compared to those of other economic activities. ${ }^{8}$ Member States have a wide margin of discretion in defining a given service as a SGEI. As stated by the Court of Justice in the BUPA judgment, the control which the EU institutions are authorized to exercise over the exercise of the Member State's discretion in determining a service of general economic interest is limited to ascertaining whether there is a manifest error of assessment. ${ }^{9}$ A definition of the public service obligation in land transport is provided in Article 2(e) of the Regulation (EC) 1370/2007. ${ }^{10}$ According to this Regulation:

6 Communication from the Commission on the application of the European Union State aid rules to compensation granted for the provision of services of general economic interest, O.J. 11.1.2012, C-8, p. 4, at para. 52. See also article 2(i) of the Regulation (EC) 1370/2007 (see note 11 below).

7 See Commission Decision of 24.2.2010 concerning public transport service contracts between the Danish Ministry of Transport and Danske Statsbaner (Case C 41/08 (ex NN 35/08)), at para. 269.

8 Communication from the Commission on the application of the European Union State aid rules to compensation granted for the provision of services of general economic interest, at para. 45; Merci convenzionali porto di Genova SpA v Siderurgica Gabrielli SpA, Case No. C-179/90, Judgment of 10.12.1991, E.C.R. 1991, p. I-5889, at para. 27; GT-Link A/S v De Danske Statsbaner (DSB), Case No. C-242/95, Judgment of 17.7.1997, E.C.R. 1997, p. I-4449, at para. 53 and Corsica Ferries France SA v Gruppo Antichi Ormeggiatori del porto di Genova Coop. arl, Gruppo Ormeggiatori del Golfo di La Spezia Coop. arl and Ministero dei Trasporti e della Navigazione, Case No. C-266/96, Judgment of 18.6.1998, E.C.R. 1998, p. I-3949, at para. 45.

9 BUPA and Others v Commission, Case No. T-289/03, Judgment of 12.2.2008, E.C.R. 2008, p. II-00081, at para. 169.

10 Regulation (EC) No 1370/2007 on public passenger transport services by rail and by road and repealing Council Regulations (EEC) No 1191/69 and (EEC) No 1107/70, O.J. 3.12.2007, L-315, p. 1. 
public service obligation means a requirement defined or determined by a competent authority in order to ensure public passenger transport services in the general interest that an operator, if it were considering its own commercial interests, would not assume or would not assume to the same extent or under the same conditions without reward.

Against the background of this definition, certain doubts may arise if only unprofitable services may be classified as public services in land transport. This is a crucial question, since many courtiers (including Poland) do not distinguish between profitable and non-profitable services but, rather, define services packages (consisting of profitable and loss-making lines). Cross-subsidization of non-profitable services by profitable services allows public expenditure to be minimized. The answer to this question was given by the European Commission in a recent decision concerning compensation provided to the Danish Railway operator DSB. ${ }^{11}$ According to the European Commission, Regulation (EC) 1370/2007 does not limit the possibility of entrusting service missions covering a set (package) of lines (routes) consisting of profitable and loss making lines in order to establish a coherent transport system, particularly with the concern of allowing a certain continuity of transport. The definition of the public service obligation does not contain the criterion of profitability of individual lines covered by public services. The European Commission stated that, if a line in a transport system is profitable, the revenue therefrom should be taken into account in the final calculation of compensation. That means that earnings from a profitable line would lead ultimately to a commensurate reduction in the financial compensation paid by public authorities in order to ensure public services on unprofitable lines. It follows from the above that the Member States do not commit a manifest error of assessment by including one or more profitable lines in a public transport service contract, insofar as those lines form part of a coherent transport system..$^{12}$ However it should be mentioned that the decision concerning compensation provided to the Danish Railway operator DSB will be subject to review by the Court of Justice in case T-92/11.

11 Commission Decision of 24.2.2010 concerning public transport service contracts between the Danish Ministry of Transport and Danske Statsbaner (Case C 41/08 (ex NN 35/08)).

12 Ibidem, at para. 263-266. 
The purpose of the second Altmark criterion is to create incentives for an undertaking entrusted with public service obligation to achieve greater economic efficiency and to prevent the danger that public service operator would unilaterally determine the scope of the public service..$^{13}$ The requirement that the parameters on which basis the compensation is calculated must be established in advance constitutes the logical consequence of the "contractual relation" between the Member States and public service operators. ${ }^{14}$ The second Altmark criterion refers not to the amount of the compensation but, rather, solely to the parameters on which basis it is calculated. It is unnecessary to determinate the exact amount of the compensation beforehand. Moreover, the need to establish the compensation parameters in advance does not mean that the compensation must be calculated on the basis of a specific formula. However, it should be clear from the outset how the compensation is to be determined..$^{15}$ According to the Court of Justice, the discretion of the Member States to determine the compensation for costs incurred in discharging an SGEI mission is not in itself incompatible with the existence of objective and transparent parameters within the meaning of the second Altmark criterion. As established in the case-law, "the Member State has a wide discretion not only when defining an SGEI mission but also when determining the compensation for the costs, which calls for an assessment of complex economic facts" ${ }^{16}$ Moreover, the Court of Justice has stated that the complexity of the economic and mathematical formulae for calculating compensation does not by itself affect the precise and clearly-determined nature of the relevant parameters. ${ }^{17}$

13 S. Santamato, Advantage in the context of services of general economic interest under Altmark [in:] W. Mederer, N. Pesaresi, M. Van Hoof (eds.), 'European Competition Law', Volume IV: State Aid, Claseys \& Casteels 2008, p. 369, at p. 375.

14 M. Kekelekis "Driving” Altmark in Land Transport, 'European State Aid Law' 2012, No. 1, p. 73, at p. 75; XXXIIIrd Report on Competition Policy 2003, Office for Official Publications of the European Communities, Brussels-Luxemburg 2004, p. 150.

15 Communication from the Commission on the application of the European Union State aid rules to compensation granted for the provision of services of general economic interest, at para. 55 .

16 Case No. T-289/03, at para. 214.

17 Case No. T-289/03, at para. 217. 
The third Altmark criterion refers to the proper calculation of compensation. This criterion is relatively easy to apply. However, sometimes it is not an easy task to establish the appropriate level of "reasonable profit". Under Regulation (EC) 1370/2007, "reasonable profit" means "a rate of return on capital that is normal for the sector in a given Member State and that takes account of the risk, or absence of risk, incurred by the public service operator by virtue of public authority intervention". The European Commission has determined the level of "reasonable profit" on a case by case basis. ${ }^{18}$ In the Southern Moravia Bus Companies case, the Commission considered that a profit of $7,85 \%$ was reasonable. ${ }^{19}$ In the decision concerning financing of public bus transport in the district of Anhalt-Bitterfeld the Commission accepted a "reasonable profit" of $5 \%$. In the DSB decision, the Commission stated that "reasonable profit" could vary in order to provide incentives for cost reductions and improvements in the quality of service. In this decision, the Commission accepted "reasonable profit" at a level of between $6 \%$ and $12 \%$, with an annual cap set at $10 \%$ over 3 years. ${ }^{20}$ In Poland, the recommended level of "reasonable profit" in the transport sector is $6 \% .{ }^{21}$ Of course, the cost of taking into account the calculation of compensation must be directly linked to the public service obligation. If a public service operator carries out activities falling both inside and outside the scope of the public service, the internal accounts must separately indicate the costs and revenues associated with the public service and those arising from other activities.

18 M. Kekelekis, op. cit., at p. 78.

19 Commission Decision of 26.11.2008 on State aid C 3/08 (ex NN 102/05), Czech Republic, concerning public service compensations for Southern Moravia Bus Companies, at para. 71 .

20 Commission Decision of 24.2.2010 concerning public transport service contracts between the Danish Ministry of Transport and Danske Statsbaner (Case C 41/08 (ex NN 35/08)), at para. 358-364.

21 Wytyczne Ministra Rozwoju Regionalnego w zakresie zasad dofinansowania z programów operacyjnych podmiotów realizujących obowiązek świadczenia usług publicznych w transporcie zbiorowym [Guidelines of the Minister of Regional Development - principles of co-financing from operational programs undertakings performing a public service obligation in public transport], at para. 117; available at: http://www.mrr.gov.pl/ fundusze/wytyczne_mrr/obowiazujace/horyzontalne/Documents/2011_5_11_wytyczne_ dof_transportu_zbiorowego_z_PO.pdf. 
In Poland, compensation is very often calculated as a fixed price per kilometre. It is doubtful whether in such cases there is no risk of overcompensation. It follows from the Commission's decision concerning state aid granted by Austria to the company Postbus in the Lienz district that this methodology is acceptable only if there are appropriate methods of comparing the amount of compensation paid to public service operator with averages found in the relevant sector ${ }^{22}$.

The first part of the fourth Altmark criterion refers to a public procurement procedure which would allow for selection of the tenderer capable of providing public services at the lowest cost to the community. Does this lead to the conclusion that all tendering procedures permitted by Public Procurement Directives are capable of fulfilling the fourth Altmark criterion? The Public Procurement Directives identify four types of tendering procedures:

- open procedures, where any interested economic operator may submit a tender, ${ }^{23}$

- restricted procedures, where any economic operator may request to participate and only candidates invited by the contracting authority may submit a tender, ${ }^{24}$

- negotiated procedures, where the contracting authority consults the economic operators of its choice and negotiates the terms of the contract with one or more of these, ${ }^{25}$

- competitive dialogue, where any economic operator may request to participate and whereby the contracting authority conducts a dialogue with the candidates admitted to that procedure, with the aim of developing one or more suitable alternatives capable of

22 Commission Decision of 26.11.2008 on State aid granted by Austria to the company Postbus in the Lienz district, C 16/07 (ex NN 55/06), at para. 77-81.

${ }^{23}$ Article 1(11)a of Directive of the European Parliament and of the Council No 2004/18/EC of 31.3.2004 on the coordination of procedures for the award of public works contracts, public supply contracts and public service contracts, O.J. 30.4.2004, L-134, p. 114-240; Article 1(9)a of Directive of the European Parliament and of the Council No 2004/17/EC of 31.3.2004 coordinating the procurement procedures of entities operating in the water, energy, transport and postal services sectors, O.J. 30.4.2004, L-134, p. 1-113.

${ }^{24}$ Article 1(11)b of Directive 2004/18/EC; Article 1(9)b of Directive 2004/17/EC.

${ }^{25}$ Article 1(11)d of Directive 2004/18/EC; Article 1(9)c of Directive 2004/17/EC. 
meeting its requirements, and on the basis of which the candidates chosen are invited to tender. ${ }^{26}$

The open procedure is obviously capable of fulfilling the fourth Altmark criterion. The restricted procedure is also acceptable, unless interested operators are prevented from tendering without valid reasons. However, both the competitive dialogue and the negotiated procedure with prior publication confer a wide discretion upon the contracting authority and may restrict the participation of interested operators. Accordingly, they may only be deemed sufficient to satisfy the fourth Altmark criterion in exceptional cases. The negotiated procedure without publication of a contract notice cannot satisfy the fourth Altmark criterion, since it is incapable of ensuring the selection of a tenderer capable of providing public services at the lowest cost to the community. ${ }^{27}$

As regards the award criteria, under the Public Procurement Directives, the competent authorities may award public service contracts on the basis of the "lowest price" tender or the "most economically advantageous tender". The "lowest price" certainly satisfies the fourth Altmark criterion. Moreover, the "most economically advantageous tender" is deemed sufficient if the award criteria, including environmental or social criteria, are closely related to the subject-matter of the service provided and allow for the most economically advantageous offer to match the value of the market. ${ }^{28}$ In cases concerning the financing of public bus transport in the district of Anhalt-Bitterfeld and the financing of transport services in the district of Wittenberg, the European Commission stated that the selection of public service operators on the basis of the best quality for a fixed price (best service for lowest cost) is sufficient to satisfy the fourth Altmark criterion. ${ }^{29}$ The contracting authority is not prevented

26 Article 1(11)c of Directive 2004/18/EC.

27 Communication from the Commission on the application of the European Union State aid rules to compensation granted for the provision of services of general economic interest, at para. 66.

28 Communication from the Commission on the application of the European Union State aid rules to compensation granted for the provision of services of general economic interest, at para. 67.

${ }^{29}$ Commission Decision No 206/2009 of 15.9.2009 concerning financing of the public transport services in district of Anhalt-Bitterfeld, at para. 48; Commission Decision No 207/2009 of 15.9.2009 concerning financing of the transport services in district of Wittenberg, at para. 45. 
from setting qualitative standards to be met by all economic operators, nor from taking into account qualitative aspects related to the different proposals into account in its award decision. ${ }^{30}$ As stated by the Court of Justice in the Concordia judgment, if:

the contracting authority decides to award a contract to the tenderer who submits the economically most advantageous tender, it may take into consideration ecological criteria such as the level of nitrogen oxide emissions or the noise level of the buses, provided that they are linked to the subject-matter of the contract, do not confer an unrestricted freedom of choice on the authority, are expressly mentioned in the contract documents or the tender notice, and comply with all the fundamental principles of Community law, in particular the principle of non-discrimination. ${ }^{31}$

Moreover, there may be circumstances in which a procurement procedure is unable to allow the selection of a tenderer capable of providing public services at the lowest cost to the community, since it does not give rise to sufficiently open and genuine competition. According to the European Commission:

this could be the case, for example, due to the particularities of the service in question, existing intellectual property rights or necessary infrastructure owned by a particular service provider. Similarly, in the case of procedures where only one bid is submitted, the tender cannot be deemed sufficient to ensure that the procedure leads to the least cost for the community. ${ }^{32}$

This constitutes a very typical situation within the transport sector. For example, the railway sectors in many countries (including Poland) often comprise merely one or two potential bidders.

30 Communication from the Commission on the application of the European Union State aid rules to compensation granted for the provision of services of general economic interest, at para. 67.

31 Concordia Bus Finland Oy Ab, formerly Stagecoach Finland Oy Ab v Helsingin kaupunki and HKL-Bussiliikenne, Case No. C-513/99, Judgment of 17.9.2002, E.C.R. 2002, p. I-07213, at point 1 of the operative part of the Judgment.

32 Communication from the Commission on the application of the European Union State aid rules to compensation granted for the provision of services of general economic interest, at para. 68. 
According to the second part of the fourth Altmark criterion, the competent authorities may determine a level of compensation on the basis of an analysis of the costs of a typical, well-run and adequately equipped undertaking (as an alternative to the public procurement procedure, which would allow the selection of a tenderer capable of providing public services at the lowest cost to the community). What is meant by the concept of a typical, well-run and adequately equipped undertaking? The Court of Justice did not provide an answer to this question. However, some remarks can be made on the basis of the Commission's decisionmaking in practice. In the decision concerning state aid granted by Austria to the company Postbus in the Lienz district, the Commission stated that, in order to ascertain whether or not the second part of the fourth Altmark criterion is met, it should be analysed separately whether the costs included in the calculation of compensation are the costs of:

- an average undertaking,

- a well-managed undertaking,

- an adequately equipped undertaking. ${ }^{33}$

In the Southern Moravia Bus Companies and Postbus cases, the European Commission noted that the statistical cost of transport undertakings in any given Member State or, in other words, average costs found in the transport sector in a given Member State may be treated as a cost of a typical undertaking. ${ }^{34}$ As to the concept of a wellmanaged undertaking, the European Commission pointed out that: "in the (...) transport sector, which has been dominated by monopolies and in which contracts have been awarded without tenders for a long time, an undertaking operating in the market is not necessarily a well-managed undertaking". Therefore the costs of an average, statistical undertaking cannot be regarded as the costs of a well managed undertaking. According to the European Commission, in order to establish the costs of a well-managed undertaking, the competent authorities can take as a basis the average

33 Commission Decision of 26.11.2008 on State aid granted by Austria to the company Postbus in the Lienz district, C 16/07 (ex NN 55/06), at para. 82.

34 Commission Decision of 26.11.2008 on State aid granted by Austria to the company Postbus in the Lienz district, C 16/07 (ex NN 55/06), at para. 83-84; Commission Decision of 26.11.2008 on State aid C 3/08 (ex NN 102/05), Czech Republic, concerning public service compensations for Southern Moravia Bus Companies, at para. 80. 
costs of undertakings which have won a significant number of tenders in the sector in the last few years. ${ }^{35}$ An adequately equipped undertaking is an undertaking which possesses the resources necessary to instantly discharge its public service obligations and to comply with the quality requirements imposed on them by law or by public authorities. ${ }^{36}$

In light of the above, it is not an easy task to fulfill the criteria laid down by the Court of Justice in the Altmark judgment. In most cases examined by the European Commission, the outcome was that the examined measure failed to satisfy all of the Altmark criteria. The most problematic is the fourth Altmark criterion, especially where the undertaking intended to discharge a public service obligation is not chosen pursuant to a public procurement procedure which would allow the selection of a tenderer capable of providing those services at the lowest cost to the community. Neither the Court of Justice nor the European Commission has provided a clear answer as to how to determine the level of compensation using an analysis of the costs of a typical, well-run, adequately equipped undertaking, nor have they provided a comprehensive explanation of what is meant by the concept of a typical, well-run, adequately equipped undertaking. It should be mentioned that the mere fact that public service compensation in land transport constitutes state aid does not mean that such compensation is unlawful per se. Such compensation is compatible with the Treaty when the conditions specified in Regulation (EC) 1370/2007 are met. However, this subject goes beyond the scope of this article.

35 Commission Decision of 26.11.2008 on State aid granted by Austria to the company Postbus in the Lienz district, C 16/07 (ex NN 55/06), at para. 85-86.

36 Communication from the Commission on the application of the European Union State aid rules to compensation granted for the provision of services of general economic interest, at para. 76; Commission Decision of 26.11.2008 on State aid, C 3/08 (ex NN 102/05), Czech Republic, concerning public service compensations for Southern Moravia Bus Companies, at para. 81. 